\title{
Marketing of shrimp in Bangladesh-A value chain analysis
}

\author{
M. S. Islam ${ }^{1}$, M. M. Haque ${ }^{2^{*}}$, M. G. Rabbani ${ }^{3}$ and S. Sharmin ${ }^{4}$ \\ ${ }^{1}$ Department of Agricultural Economics, ${ }^{2}$ Graduate Training Institute, Bangladesh Agricultural University, \\ Mymensingh-2202, Bangladesh, ${ }^{3}$ Department of Economics, Hajee Mohammad Danesh Science and Technology \\ University, Dinajpur, Bangladesh and ${ }^{4}$ Programme of Nutrition, School of Health Science, University Sains Malaysia, \\ Kota Bharu, Kelantan, Malaysia, ${ }^{*}$ E-mail: mojammel_haque@yahoo.com
}

\begin{abstract}
Shrimp is an important fisheries resource in the national economy of Bangladesh. It is considered as an exportable item and in each year it shared about $2.75 \%$ of the total export earning of Bangladesh. The present study was conducted to examine the marketing system and value chain, and marketing efficiency of shrimp marketed both in domestic and export market. For this study a total of 182 stakeholders (market intermediaries) were selected where shrimp farmers, export oriented farms, depot owners and other market participants and selling agents were included. Data were collected for the period of $2012-13$. The study revealed that $80 \%$ shrimp is exported and rest $20 \%$ is consumed in the local market. Usually shrimp is exported through exporting agencies and firms. Considering all kinds of market, the average gross marketing margin and profit of shrimp in the local market were Tk 171.00/kg and Tk $134.04 / \mathrm{kg}$ respectively but for export market, the corresponding amounts were Tk 142.76/kg and Tk 89.51/kg respectively. Shrimp is sold both in domestic and overseas market and accordingly major supply chain and value chain were identified. Shrimp farmers and exporting agencies supply shrimp to ultimate consumers through supply chain. Actually value chain actors added value at each level of market. After processing and adding value, domestic and overseas consumers purchase $1 \mathrm{~kg}$ of shrimp at Tk 55.00 and Tk 142.76 respectively. Marketing efficiency was studied only for domestic market. It revealed that shorter supply channel resulted efficient marketing of shrimp where the shrimp producer received the higher percentages of sales price provided by the retailer in consumer market.
\end{abstract}

Keywords: Marketing, Shrimp, Value chain, Marketing efficiency

\section{Introduction}

Fishery is an important renewable resource in Bangladesh. Bangladesh is endowed with vast marine and brackish water resources having fisheries potentials. Contribution of fisheries sector in the national economy of Bangladesh is substantial, particularly with reference to food consumption, nutrition, employment and export. This sector contributes about $4.43 \%$ to GDP and $2.73 \%$ to foreign exchange earnings through export (BBS, 2010-11). The sector provides full time employment for 1.56 million professional fishermen and 11 million part time fisher folk, which is about $10.5 \%$ of the total population (DoF 2012).

There are two production zones for shrimp in Bangladesh, the southern region and the Chittagong region. The southern region contributes about $70 \%$ of the total shrimp production $(55,513 \mathrm{mt}$ ) of Bangladesh(BBS 2010-11). The rest of the production is mostly concentrated in the coastal region in Chittagong and Cox's Bazaar. The total land under shrimp production in the southern region is estimated to be183,000 ha. This is about $75 \%$ of the total land under shrimp and prawn production in the region (World Fish, 2011).Within the southern region, Satkhira, Bagerhat and Khulna are the major production hubs.

Brood shrimps are collected from the deep sea. Only a few large hatcheries which have fishing trawlers/vessels can collect brood shrimp directly from the sea. Shrimp hatcheries are mostly located in coastal region in Cox's Bazar. It is estimated that there are around 60 operational shrimp hatcheries in coastal areas of Bangladesh. Currently European Union (EU) is the largest importer of shrimp accounting for $60 \%$ of the total export of shrimp and prawn from Bangladesh (BFFEA, January-April 2012). Overall, both the volume and the value of export of shrimp from Bangladesh has declined in 2011-12 fiscal year as opposed to the 2010-11 fiscal year. Data from the Department of Fisheries (DoF) revealed that the volume of export of shrimp reduced from 40,860 MT in 2010-11 to 35,678 MT in 2011-12. During the same period, total value of shrimp exported declined from US\$365 million to US\$ 322 million. 
Market chain analysis aims to provide information on profitability for the various agents along the market chain (Ferris et al., 2001). Economic value chain analysis describes the range of activities required to bring a product to the final consumer and, in the case of international products, the extent to which intermediaries/agents gain from participating in the chain (Jacinto, 2004). A traditional food industry value chain consists of the producer, processor, wholesaler, exporter, importer, retailer and consumer. Analysis of value chains requires detailed micro-level data, which are not available in Bangladesh and are often difficult to obtain in most countries. The present study takes the first steps to collect primary data and to identify the marketing channels and value addition of shrimp in Bangladesh. This study analyzes how market intermediaries operate along shrimp value chains. This study also provides information on shrimp in Bangladesh to support the statistical report linking the value chain in shrimp supply. Finally, this study is expected also to provide some useful information to traders, fisherman and policy makers to help them formulate programmes and policies related to the concerned shrimp production and marketing.

A very few researches (Islam et al., 2006; Islam et al. 2001;Roheim, 2008; Taylor, 2005) were conducted on marketing and value chain system of shrimp produced in Bangladesh. Considering shrimp production and distribution it was an urgent need to study on shrimp marketing and its value chain system. In this regard, the present study was conducted to examine the marketing system, marketing efficiency, supply chain and value addition to shrimp, and intermediaries or actors involved in marketing of shrimp in Bangladesh.

\section{Materials and Methods}

For marketing of shrimp, a field level surveys as well as FGD were conducted to have detailed information about marketing system of shrimp. However, data were collected both from primary and secondary sources. Secondary data were collected from various exporting firms and offices, and consulted with the documents of government and non-government agencies such as Bangladesh Frozen Food Export Association (BFFEA), Bangladesh Export Promotion Bureau (BEPB), BFDC, Fish Inspection and Quality Control (FIQC), DoF, marketing cooperatives etc. Primary data were collected by survey method wherein various market intermediaries were interviewed for eliciting information at various stages of shrimp. Apart from these, formal interview with shrimp producers, concerned traders and buyers were conducted for cross checking the marketing information. Again, FGD was conducted to have detailed information from the stakeholders involved in supply or value chain system of shrimp marketed.

The study areas were purposively selected from Cox's Bazar, Chittagongand Khulna, and extended market Dhaka city, Saidpur (Nilphamari) and Mymensingh city market depending upon the production and marketing of shrimp. In these study areas, three types of market such as primary market, secondary market and consumer market were selected. The sampling design for marketing survey falls within the purview of stratified random sampling. In the whole marketing channel the intermediaries constitute the different strata from which the individual samples were selected randomly.

Large number of market intermediaries or actors such as faria, bepari, localaratder, inter-district aratdar and retailer are available in shrimp market of Bangladesh. Shrimp are also available in different city fish market where mainly the consumers purchase shrimp from the retailers.

The total number of samples depends on the number of intermediaries involved in the marketing channel. Therefore, from primary to final consumer market, there is a long chain and value addition, and complicated marketing channel for distribution of shrimp both in domestic and export market. In each level of market, how small and poor stakeholders participate in shrimp processing and marketing, and contribute to value addition to marketing channel had also been studied. However, considering the scale of involvement of different kinds of intermediaries, a total of 182 samples were selected of which shrimp farmer were 40, faria35, bepari 40, local aratdar15, inter-district aratdar 15 and retailer 30. For export market, data and information were collected from 7 export oriented farms and agencies. 


\section{Analytical technique}

The data and information so collected were reduced to tabular form which included classification of tables into meaningful results by using arithmetic mean, percentage and ratio. For shrimp marketing, intermediaries involved in marketing channel were identified and marketing costs and margins and producers' share and marketing efficiency were determined by using following formula and the estimated values were placed in tables for easy to understand. Supply chain, value chain and value addition to shrimp is shown by flow channel.

Marketing cost: Marketing cost is the sum of transport cost, storage cost, labour cost and other costs associated with moving the commodity from the point of purchase to the customer or final consumer. The total marketing cost was determined by the following formula

$\mathrm{Tc}=\mathrm{Cp}+\sum \mathrm{Mci}$

Where, $\mathrm{i}=1 ; \mathrm{Tc}=$ Total cost of marketing; $\mathrm{Cp}=$ Producer cost of marketing; $\mathrm{Mci}=$ Marketing cost by the ith trader

Marketing margin: The absolute margin of the middleman, wholesaler, trader and retailers was determined as follows

$\mathrm{Mm}=\mathrm{Psa}-(\mathrm{Pba}+\mathrm{Mc})$

Where, $\mathrm{Mm}=$ Marketing margin; $\mathrm{Psa}=$ Selling price $; \mathrm{Pba}=$ Buying price; $\mathrm{Mc}=$ Marketing cost

The cost of marketing was calculated and the lowest cost marketing channel was ranked I and that of highest cost marketing channel was considered as last one. The same approach was followed in ranking the margin of middlemen in each channel.

Producer's share: The producer's share was derived by the ratio of net average price received by the producers to the average price of shrimp, which was calculated with the following formula and the channel which had highest producer's share was ranked (1) and first and vice-versa.

Percentage of producer' s share $=\frac{\mathrm{P}_{\mathrm{pi}}}{\mathrm{P}_{\mathrm{ri}}} \times 100$

Where, $\mathrm{P}_{\mathrm{pi}}=$ Producer's share in the ith channel; Pri= Average price at the retail level in each channel; $i=$ Number of channels $(\mathrm{i}=1,2 \ldots \ldots \ldots, \mathrm{n})$

\section{Measuring marketing efficiency}

Marketing efficiency is directly related to the cost involved in moving goods from the producer to the consumer and the quantity of services offered. If the cost incurred when compared with the services involved, was low, it would be efficient marketing. The improvement in marketing efficiency means the reduction of marketing cost without reducing the quantum of services to the consumer.

Efficient marketing plays an important role in increasing the producer's share in consumer's Taka (BD Tk) and maintains the tempo of increased production. Three indicators like; (i) marketing cost; (ii) marketing margin and (iii) Percentage of producer's share were used in this study for measuring efficiency in different marketing channels. Thamizhselvan and Murugan (2012) used four methods i.e. Shepherd's Method, Acharya and Aggarwal's Method, Composite Index Method and Marketing Efficiency Index Method to calculate marketing efficiency. According to the availability of data and information, Composite Index Method was followed to estimate marketing efficiency for the present study. 


\section{Composite index method}

As per this method, the percentage of producer's price, marketing cost and marketing margin to consumer's price per $\mathrm{kg}$ of shrimp are calculated and ranked. Total scores are found by adding the respective ranks in each channel. The mean scores are calculated for each channel. Where the mean score is less, it is efficient channel (Thamizhselvan and Murugan, 2012).

$\mathrm{R}=\frac{\mathrm{R}_{\mathrm{i}}}{\mathrm{N}_{\mathrm{i}}}$

Where, $R_{i}=$ Total value of ranks of all indicators $\left(I_{1}, I_{2}\right.$ and $\left.I_{3}\right) ; N_{i}=$ Number of indicators

\section{Results and Discussion}

\section{Marketing system of shrimp}

Shrimp farmers sold $70 \%$ of their fishes to farias and that of $30 \%$ to beparis via aratdars. On the other hand, farias purchased $100 \%$ shrimp from shrimp farmers and they sold $86 \%$ to depot owners via depot employees. Bepari purchased entire fish (100\%) from faria via aratdar and sold $57 \%$ to depots via depot employees, $21 \%$ of inter district aratdar agent via aratdar and rest $14 \%$ from retailers. Inter-district aratdar agent purchased 33\% from faria and 67\% from bepari via aratdar but they sold entire fish to ultimate retailers. Depot owners purchased $75 \%$ and $25 \%$ shrimp from faria and bepari via aratdar respectively and sold entire amount (100\%) to exporting farms/processing plant. Again, processing plant or exporting farm purchased shrimp mainly from depot owner (100\%) and exported the entire amount to abroad. Usually the consumers purchased $100 \%$ of shrimp from the retailers in the study areas (Table 1).

Table 1. Percent of culture shrimp transacted by value chain actors

\begin{tabular}{|c|c|c|c|c|c|c|c|c|c|c|c|c|c|c|}
\hline \multirow{2}{*}{$\begin{array}{l}\text { Value chain } \\
\text { actor }\end{array}$} & \multicolumn{6}{|c|}{ Purchase from (\%) } & \multicolumn{8}{|c|}{ Sold to (\%) } \\
\hline & 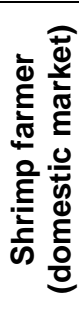 & $\begin{array}{l}\frac{\pi}{\pi} \\
\frac{\pi}{\pi} \\
\frac{\pi}{\pi} \\
. \frac{\pi}{\pi} \\
\frac{\pi}{\pi}\end{array}$ & $\begin{array}{l}\frac{1}{\pi} \\
\frac{\pi}{\pi} \\
\frac{\pi}{\pi} \\
: \frac{\pi}{2} \\
: \frac{\pi}{\pi} \\
\frac{0}{0}\end{array}$ & 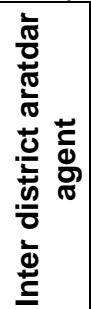 & 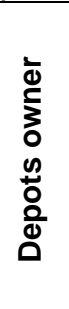 & $\frac{\text { ప }}{\frac{\pi}{\pi}}$ & $\underset{\sim}{\stackrel{\pi}{\pi}} \underset{\leftarrow}{\mathbb{\pi}}$ & $\begin{array}{l}\frac{1}{\pi} \\
\frac{\pi}{\pi} \\
\frac{\pi}{\pi} \\
: \frac{\pi}{\pi} \\
: \frac{\pi}{d} \\
0 \\
0\end{array}$ & 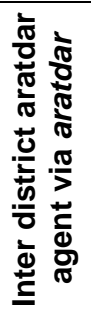 & 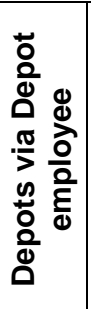 & 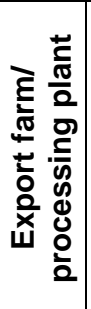 & 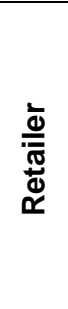 & 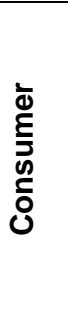 & 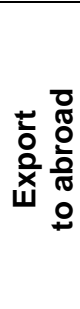 \\
\hline Shrimp farmer & - & - & - & - & - & - & 70 & 30 & - & - & - & - & - & - \\
\hline Faria & 100 & - & - & - & - & - & - & 7 & 7 & 86 & - & - & - & - \\
\hline Aratdar & \multicolumn{14}{|c|}{$\begin{array}{c}\text { Aratdars negotiate between buyers and sellers of fish and help them at their own business } \\
\text { premises on receipt of Aratdari commission. }\end{array}$} \\
\hline Bepari & - & 100 & - & - & - & - & - & - & 29 & 57 & - & 14 & - & - \\
\hline $\begin{array}{l}\text { Inter district } \\
\text { aratdar agent }\end{array}$ & - & 33 & 67 & - & - & - & - & - & - & - & - & 100 & - & - \\
\hline Depots & - & 75 & 25 & - & - & - & - & - & - & - & 100 & - & - & - \\
\hline Export farm & - & - & - & - & 100 & - & - & - & - & - & - & - & - & 100 \\
\hline Retailer & - & - & - & & & & - & - & - & - & - & - & 100 & - \\
\hline Consumer & - & - & - & - & & - & & - & - & - & - & - & - & - \\
\hline
\end{tabular}

\section{Marketing and supply chain of shrimp}

Marketing channels are the alternative and/or different routes of product flows from producers to ultimate consumers. Value chain is the addition of added value provided by market participants (actors) in different levels of market of respective product. However, value chain may be short or long for a particular commodity depending on the qualities of products, size and nature of consumers and product producers and the prevailing social and physical environment (Alam et al., 2011). Again, value chains are dominated by supply chains of respective product. Moreover, it indicates how products are supplied and distributed from producers to consumers and then how additional values are added in supply chain by providing efforts and services by the market participants at different levels of market. 
Shrimp is considered as export oriented products. Both shrimp has two sources of production-culture and capture. Flow Chart 1 show the distribution and supply chain system of shrimp produced and collected in the study areas. In fish exporting market, along with supplier, depot and processing plant owners and exporting agencies are involved and play key role in exporting shrimp. It may be noted that frozen shrimp has high demand in export market and about 80-95\% shrimp are exported in abroad including EU and Non-EU countries of the world. Accordingly Flow chart 1 shows same figures and amount as exported through different supply chain for shrimp.

\section{Marketing cost of shrimp}

Marketing costs represent the cost of performing various marketing functions which are needed to transfer a commodity from the place of production to the ultimate consumers. In shrimp marketing, nature and types of costs at different stages in marketing process are not identical due to dissimilarities of marketing functions at various stages. As shown in Table 2 that mainly five types of intermediaries viz., faria, aratdars, beparies, inter-district aratdar agent and retailers were found to be involved in shrimp marketing. These five categories of intermediaries perform different marketing operations and functions and accordingly, there is a large variation in marketing cost incurred by the intermediaries. However, marketing costs for each $\mathrm{kg}$ of shrimp were estimated to be Tk 6.19, 5.07, 1.19, 10.17, 8.19 and 5.43 for shrimp farmer, faria, aratdar, beparies, inter-district aratdars and retailers respectively (Table 2). In lieu for taking commission, aratdars simply help bepariesto sell their products and collect buyers (retailers) to purchase it without taking any risk of loss or damage of fish. Accordingly, aratdar's marketing cost was lower (Tk 1.19/kg) compared to that of other intermediaries. The processing plant (or export firms/ agencies) incurred cost Tk 54.19 per kg for exporting shrimp (Table 3).

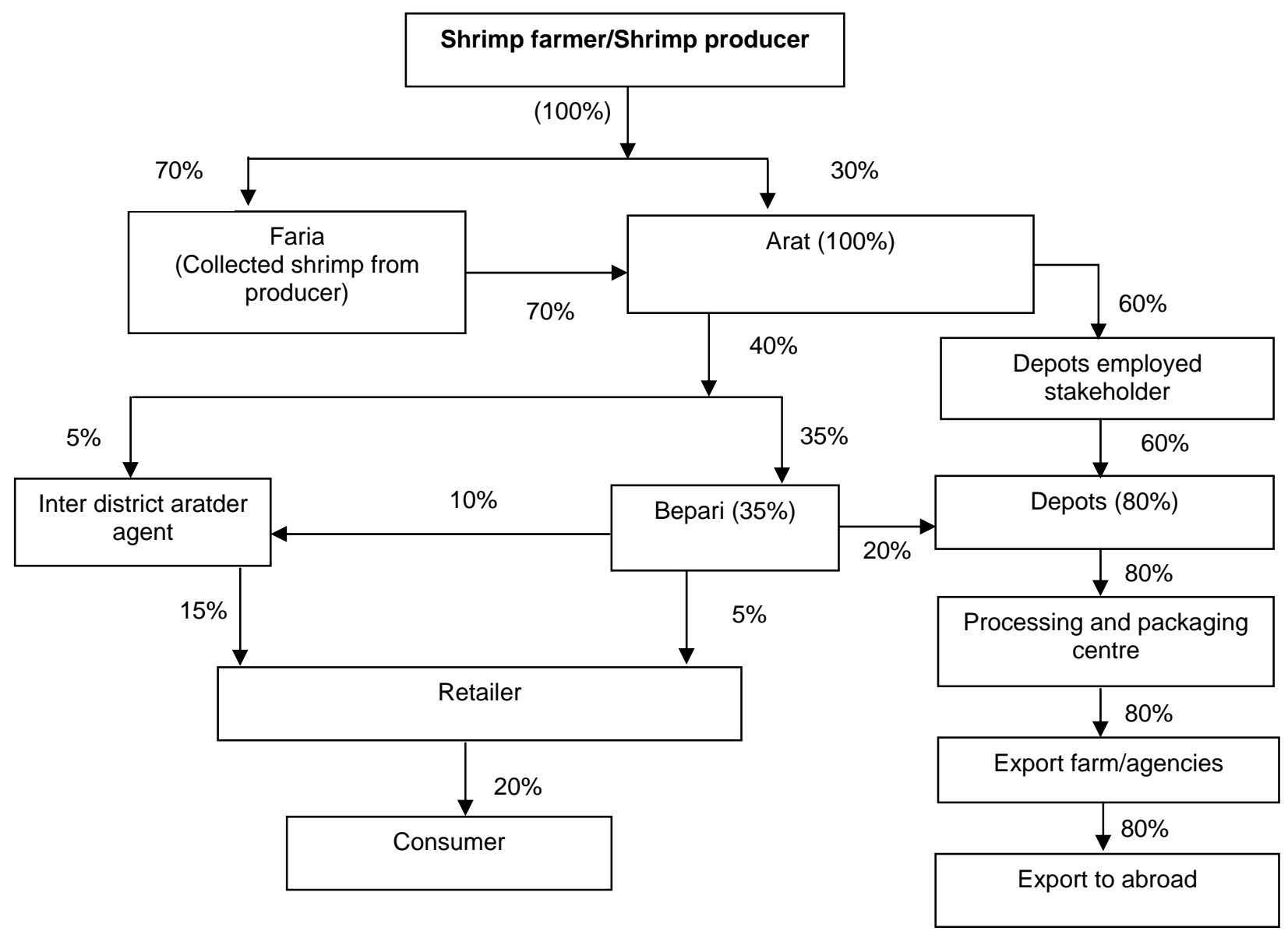

Flow chart 1 Marketing and supply chain system of shrimp 


\section{Supply chains of the shrimp marketing}

Chain-1: Shrimp farmer $\rightarrow$ Faria $\rightarrow$ Arat $\rightarrow$ Inter district aratder agent $\rightarrow$ Retailer $\rightarrow$ Consumer $=5 \%$

Chain-2: Shrimp farmer $\rightarrow$ Pharia $\rightarrow$ Arat $\rightarrow$ Bepari $\rightarrow$ Inter district aratder agent $\rightarrow$ Retailer $\rightarrow$ Consumer $=10 \%$

Chain-3: Shrimp farmer $\rightarrow$ Arat $\rightarrow$ Bepari $\rightarrow$ Retailer $\rightarrow$ Consumer $=5 \%$

Chain-4: Shrimp farmer $\rightarrow$ Arat $\rightarrow$ Bepari $\rightarrow$ Depots $\rightarrow$ Processing and packaging centre $\rightarrow$ Export farm/agencies $\rightarrow$ Export to abroad $=20 \%$

Chain-5: Shrimp farmer $\rightarrow$ Arat $\rightarrow$ Depots employed stakeholder $\rightarrow$ Depots $\rightarrow$ Processing and packaging centre $\rightarrow$ Export farm/agencies $\rightarrow$ Export to abroad $=60 \%$

Table 2. Total marketing cost of stakeholders and intermediaries involved in shrimp marketing $(T k / k g)$ in domestic market

\begin{tabular}{|l|c|c|c|c|c|c|c|c|}
\hline Cost items & $\begin{array}{l}\text { Shrimp } \\
\text { farmer }\end{array}$ & Faria & Aratdar & Bepari & $\begin{array}{c}\text { Int.-district } \\
\text { aratdar agent }\end{array}$ & Retailer & $\begin{array}{c}\text { Total } \\
\text { \% of } \\
\text { total }\end{array}$ \\
\hline $\begin{array}{l}\text { Transportation, loading } \\
\text { and unloading }\end{array}$ & 1.40 & 1.76 & 0.00 & 3.37 & 3.70 & 1.71 & 11.94 & 32.30 \\
\hline Baskets & 0.28 & 0.14 & 0.06 & 1.13 & 0.00 & 0.45 & 2.04 & 5.53 \\
\hline Icing & 0.00 & 0.00 & 0.00 & 1.41 & 0.00 & 0.89 & 2.30 & 6.21 \\
\hline Wage and salaries & 0.00 & 0.18 & 0.63 & 0.19 & 0.43 & 0.00 & 1.43 & 3.88 \\
\hline Aratdar's commission & 2.63 & 2.30 & 0.00 & 2.64 & 2.30 & 0.00 & 9.87 & 26.70 \\
\hline House rent & 0.00 & 0.00 & 0.15 & 0.03 & 0.01 & 0.62 & 0.81 & 2.19 \\
\hline Security & 0.00 & 0.00 & 0.01 & 0.00 & 0.00 & 0.06 & 0.06 & 0.17 \\
\hline Electricity & 0.00 & 0.00 & 0.12 & 0.00 & 0.15 & 0.15 & 0.42 & 1.12 \\
\hline Telephone bill & 0.12 & 0.11 & 0.14 & 0.17 & 0.09 & 0.34 & 0.97 & 2.63 \\
\hline Personal expenses & 0.15 & 0.12 & 0.19 & 0.23 & 0.18 & 0.51 & 1.38 & 3.72 \\
\hline Tips and donation & 0.14 & 0.21 & 0.12 & 0.18 & 0.19 & 0.15 & 0.99 & 2.67 \\
\hline Wastage & 0.15 & 0.00 & 0.00 & 0.00 & 0.58 & 0.00 & 0.74 & 1.99 \\
\hline Others & 1.33 & 0.25 & 0.50 & 0.82 & 0.56 & 0.56 & 4.02 & 10.88 \\
\hline Total & $\mathbf{6 . 1 9}(\mathbf{1 6})$ & $\mathbf{5 . 0 7}(\mathbf{1 3 )}$ & $\mathbf{1 . 9 1} \mathbf{( 5 )}$ & $\mathbf{1 0 . 1 7 ( 2 7 )}$ & $\mathbf{8 . 1 9}(\mathbf{2 2})$ & $\mathbf{5 . 4 3} \mathbf{( 1 4 )}$ & $\mathbf{3 6 . 9 7}(\mathbf{1 0 0})$ & $\mathbf{1 0 0 . 0}$ \\
\hline
\end{tabular}

Table 3. Cost of export firms for exporting shrimp (Tk/kg) in export market

\begin{tabular}{|l|c|}
\hline Cost items & Dry fish (Jew fish, Pomfret, Coral, Bombay duck and Surma) \\
\hline Transportation, loading and unloading & 4.02 \\
\hline Baskets & 3.20 \\
\hline Icing & 1.50 \\
\hline Wage and salaries & 10.50 \\
\hline Electricity & 0.13 \\
\hline Medicine and salt & 0 \\
\hline Telephone bill & 0.21 \\
\hline Personal expenses & 0.25 \\
\hline Packaging for export & 11.20 \\
\hline Storage & 1.81 \\
\hline Commission paid ${ }^{1}$ & 2.36 \\
\hline Freight & 15.41 \\
\hline Wastage & 0.10 \\
\hline Others & 3.50 \\
\hline Total & 54.19 \\
\hline
\end{tabular}

${ }^{1}$ cost incurred for commission paid to supplier, charges of clearing and forwarding, shipment etc. 


\section{Marketing margin, profitability and efficiency of shrimp marketed}

According to Kohls and Uhl (2005), marketing margin in a sense is the price of all utility adding activities and functions that are performed by the intermediaries. A marketing margin is the percentage of the final weighted average selling price taken by each stage of the marketing chain. The margin must cover the costs involved in transferring produce from one stage to the next and provide a reasonable return to those doing the marketing activities. (Crawford, 1997). It is also termed as price spread as it represents the difference between the buying and selling price. Total marketing margin is the difference between the price received by shrimp farmers and the price paid by the final consumers.

Marketing margin and marketing cost are usually used to estimate the profitability of intermediaries involved in shrimp marketing. Marketing margin at a particular stage of transaction is the difference between sales price and purchase price while marketing profit is the difference between the marketing margin and marketing cost for each species of fish marketed. Total marketing margin is the difference between the price received by the producer and the price paid by consumer. Marketing margin is the price for adding activities and functions performed by intermediaries (Kohls and Uhl 1980).

Local consumption of shrimp is very low in Bangladesh. But considering its importance, marketing margin and profit in domestic market were determined. Table 4shows that, in all respect both marketing margin and marketing profit of shrimp in domestic market were Tk 171 and Tk 134.04 respectively. In most of the cases cultured shrimp are supplied directly to depot owners by bepari and respective farmers and then these are exported by exporting firms or agencies. Exporting agencies earned Tk 89.51/kg of shrimp.

Table 4. Value addition and marketing profit of shrimp in domestic and export market $(\mathrm{Tk} / \mathrm{Kg})$

\begin{tabular}{|c|c|c|c|c|c|}
\hline \multirow[t]{2}{*}{ Particulars } & \multicolumn{4}{|c|}{ Domestic Market } & \multirow{2}{*}{$\begin{array}{l}\text { Export } \\
\text { Market }\end{array}$} \\
\hline & $\begin{array}{c}\text { Primary } \\
\text { Market }\end{array}$ & $\begin{array}{c}\text { Secondary } \\
\text { Market }\end{array}$ & $\begin{array}{c}\text { Consumer } \\
\text { Market }\end{array}$ & $\begin{array}{l}\text { Total marketing } \\
\text { margin and profit }\end{array}$ & \\
\hline Purchase price (PP) & 524.00 & 580.00 & 640.00 & - & 760.30 \\
\hline Marketing cost (MC) & 11.26 & 12.08 & 13.62 & - & 53.25 \\
\hline Sales price $(\mathrm{SP})$ & 580.00 & 640.00 & 695.00 & - & 903.06 \\
\hline $\begin{array}{l}\text { Marketing margin } \\
(\mathrm{MM}=\mathrm{SP}-\mathrm{PP})\end{array}$ & 56.00 & 60.00 & 55.00 & 171.00 & 142.76 \\
\hline $\begin{array}{l}\text { Marketing profit } \\
(\mathrm{MP}=\mathrm{MM}-\mathrm{MC})\end{array}$ & 44.74 & 47.92 & 41.38 & 134.04 & 89.51 \\
\hline
\end{tabular}

\section{Value chain analysis of shrimp}

The value chain describes the full range of activities, which are required to bring a product or service from conception, through the different phases of production, delivery to final consumers (Kaplinsky and Morris, 2000). In reality, value chain tends to be extended with a whole range of activities within each link and links between different value chains. Despite the inherent complexity, value chain analysis can deepen inquiry into the disjuncture between high level of economic integration into national and global product markets and the extent to which countries and people actually gain from such integration (Jacinto, 2004). Value chain analysis, in this context, is an innovative tool that developing countries should consider. 


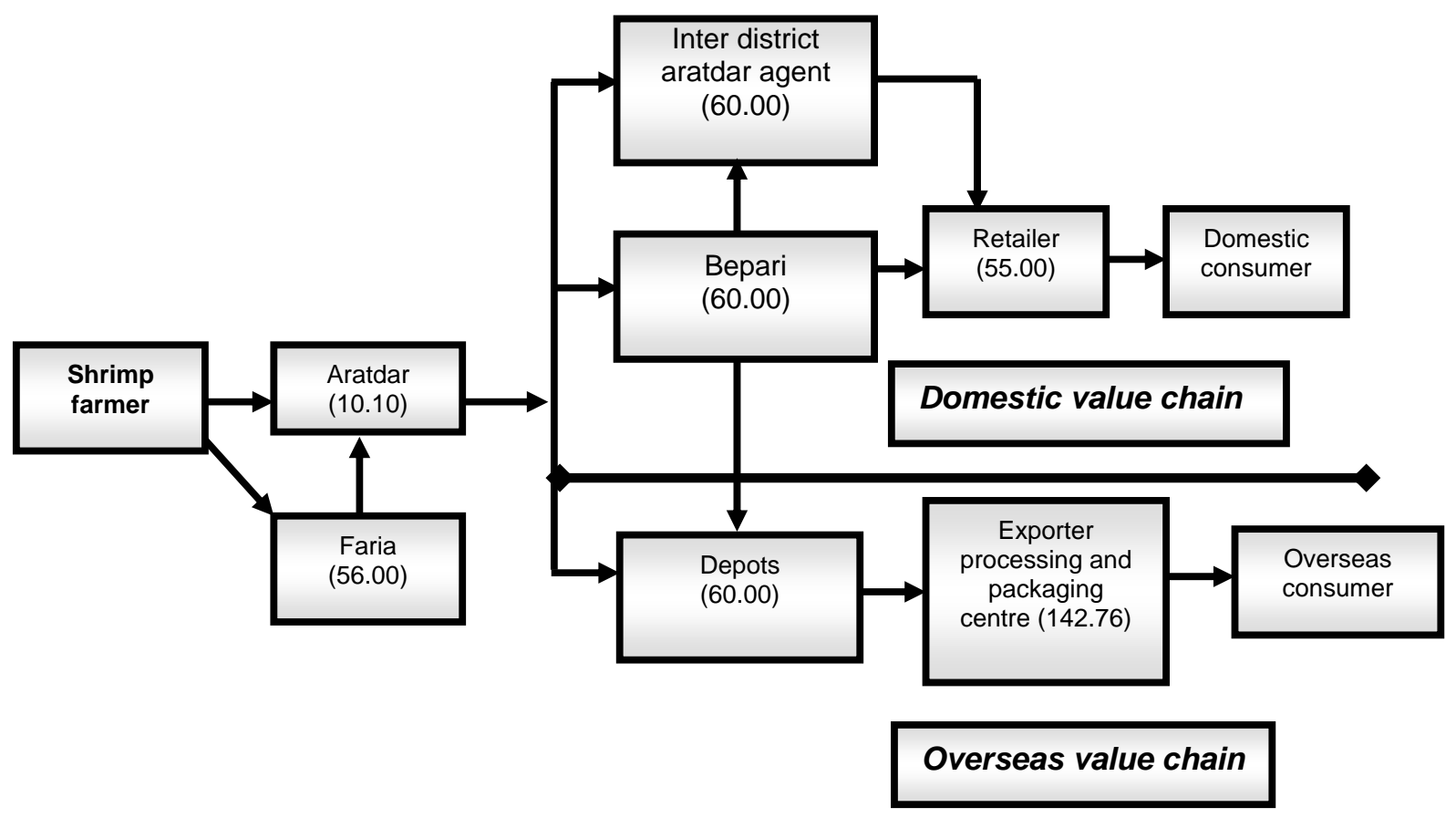

Fig. 1. Value chains of shrimp in domestic and export market

Source: Field survey 2012.

Note: Figures in the parenthesis indicate the average gross marketing margin/added value (Tk/kg) by value chain actors. Local and distant bepari were considered to add same value (marketing margin) otherwise it is difficult and complex to measure their average value.

\section{Marketing efficiency of shrimp}

Shrimp farmers' share under different marketing channel: From Table 5, it could be seen that the share of the shrimp farmer's in the price paid by the consumer is $72.60,76.54$ and $76.97 \%$ in channel II, I and III respectively. It is found to be the highest in channel III when compared to channel I and II.

Table 5. Shrimp farmers' share under different marketing channel (\%)

\begin{tabular}{|l|c|c|c|}
\hline Particulars & Channel-1 & Channel -2 & Channel -3 \\
\hline Farmers' price (Tk/kg) & 547.43 & 495.3 & 529.28 \\
\hline Consumer/ retail price (Tk/kg) & 715.2 & 682.21 & 687.6 \\
\hline Percentage of farmer' share (\%) & 76.54 & 72.60 & 76.97 \\
\hline Rank $\left(\mathrm{I}_{1}\right)$ & II & III & I \\
\hline
\end{tabular}

Source: Field survey 2012

Marketing cost and margin of different channels of shrimp: It is evident from the Table 6, the marketing cost of shrimp was less in channel III (Tk.23.70/kg) and highest in channel II (Tk.36.97/kg). The marketing margin received by the intermediaries was the highest in channel II (Tk.186.91/kg) and the lowest in channel III (Tk.158.32/kg). 
Table 6. Marketing cost and margin of shrimp different marketing channel of shrimp (Tk/kg)

\begin{tabular}{|l|c|c|c|}
\hline Particulars & Channel-1 & Channel -2 & Channel -3 \\
\hline Farmers' price & 547.43 & 495.3 & 529.28 \\
\hline Consumer/ retail price & 715.2 & 682.21 & 687.6 \\
\hline Marketing margin & 167.77 & 186.91 & 158.32 \\
\hline Rank $\left(\mathrm{I}_{2}\right)$ & $\mathrm{II}$ & III & I \\
\hline Marketing cost & 26.79 & 36.97 & 23.70 \\
\hline Rank $\left(\mathrm{I}_{3}\right)$ & $\mathrm{II}$ & III & I \\
\hline
\end{tabular}

Source: Field survey 2012

Efficiency of different marketing channels of shrimp: According to the Composite Index Method channel III (Shrimp farmer $\rightarrow$ Arat $\rightarrow$ Bepari $\rightarrow$ Retailer $\rightarrow$ Consumer) is the most efficient channel than that of other channels (Table 7). It is also evident that this is the shorter channel for shrimp marketing.

Table 7. Marketing efficiency of shrimp under composite index method

\begin{tabular}{|c|c|c|c|c|c|c|}
\hline \multirow{2}{*}{$\begin{array}{l}\text { Marketing } \\
\text { Channel/Rank }\end{array}$} & \multicolumn{6}{|c|}{ Score as performance indicators } \\
\hline & $\begin{array}{c}\text { Producers } \\
\text { share }(\%)\left(I_{1}\right)\end{array}$ & $\begin{array}{l}\text { Marketing margin } \\
(T k / k g)\left(I_{2}\right)\end{array}$ & $\begin{array}{c}\text { Marketing cost } \\
(\mathrm{Tk} / \mathrm{kg})\left(\mathrm{I}_{3}\right)\end{array}$ & $\begin{array}{l}\text { Total } \\
\text { score }\end{array}$ & $\begin{array}{l}\text { Mean } \\
\text { score }\end{array}$ & Rank \\
\hline Channel-1 & 76.54 & 167.77 & 26.79 & \multirow{2}{*}{6} & \multirow{2}{*}{2} & \multirow{2}{*}{ II } \\
\hline Rank & 2 & 2 & 2 & & & \\
\hline Channel -2 & 72.60 & 186.91 & 36.97 & \multirow{2}{*}{9} & \multirow{2}{*}{3.0} & \multirow{2}{*}{ I } \\
\hline Rank & 3 & 3 & 3 & & & \\
\hline Channel -3 & 76.97 & 158.32 & 23.70 & \multirow{2}{*}{3} & \multirow{2}{*}{1.0} & \multirow{2}{*}{ III } \\
\hline Rank & 1 & 1 & 1 & & & \\
\hline
\end{tabular}

Source: Field survey 2012

Note: Marketing efficiency estimated by Composite Index Method

\section{Conclusion and Recommendation}

Brackish water and marine fish contributes about $19 \%$ to total fish production in Bangladesh. Shrimp as an exportable item seems to have brought some improvement in the value chain. Since commercial shrimp farmers are relatively rich and large farmers, they are not dependent much on others for credit, farming practices and input uses and marketing decisions. By virtue of their richness, they remain aware of the market price. Therefore, the farm gate price they receive reflects the market price. As a result, they get relatively higher share (73-77\%) of the consumer's price. After their harvest, some farmers directly approach aratdars and depot owners to sell their harvested shrimp. The farmers usually bring shrimp to deport or processing factory, who then made arrangement for processing and shipment.

Market regulations needs to be strictly followed. Monitoring to ensure fish quality needs to be strengthened. Similarly, it is also the responsibility of the government to have strong monitoring so that consignment can reach the destination in time. The development of good road and transport networks could reduce superfluous involvement of intermediaries, which could be beneficial for both the fishermen/farmers and consumers. Assembling centers with refrigerated storage facilities might be developed so that the perishability of shrimp is checked, which would enable the assembling centers to make bulk sell/transfer to the next destination. This could reduce post-harvest loss and provide better price for the fishermen/farmers. All these facilities would create opportunity to add more value for shrimp and distribution to the consumers' level. 


\section{References}

Alam, M.F, Polash, M.S, Mia, M.I.A. and Dey, M.M. 2011. Marketing of Major Fish Species in Bangladesh. A Value Chain Analysis. A report submitted to Food and Agricultural Organization for the project entitled "A Value Chain Analysis of International Fish Trade and Food Security with an Impact Assessment of the Small-Scale Sector." FAO and Government of Bangladesh.

BBS. 2010-2011. Yearbook of Agricultural Statistics of Bangladesh, Bangladesh Bureau of Statistics, Dhaka.

BFFEA. January-April 2012. Shrimp \& Fish: Newsletter of BFFEA. BFFEA. DoF. Fish and Fisheries Export Data July2011-June 2012.

Crawford, I.M. 1997. Agricultural and Food Marketing Management. Food and Agricultural Organization of the United Nations, Rome, pp.261-262.

DoF. 2012. Fishery Statical Yearbook of Bangladesh, Fisheries Resource Survey System, Department of Fisheries, Bangladesh.

Ferris R.S.B., Collinson C., Wanda K., Jagwe J. and Wright P. 2001. Evaluating the marketing opportunities for shea nut and shea nut processed products in Uganda. A report prepared for USAID. P.77.

Islam, M. S., Akteruzzaman, M., and Ahmed, N. 2006. Study on marketing and value chain of some commercially important coastal and marine aquatic products of Bangladesh. Research Report, Bangladesh Fisheries Research Forum, Dhaka, Bangladesh.

Islam, M.S., Miah, M.T.H. and Haque, M. M. 2001. Marketing system of Marine fish in Bangladesh: An Empirical Study. The Bangladesh Journal of Agricultural Economics, 24 (1\&2), 127-142.

Jacinto, E.R. 2004. A research framework on value chain analysis in small-scale fisheries. Tambuyog Development Center, the Philippines

Kohls and Uhl. 2005. Marketing of Agricultural Products. Macmillan Publishing Co., Inc., New York.

Kaplinsky, R. and Morris, M. 2000. A Handbook for Value Chain Research. International Development Research Center (IDRC). Ottawa, Canada.

Roheim C.A. 2008. Seafood Supply Chain Management: Methods to Prevent Illegally-Caught Product Entry into the Market place, Department of Environmental and Natural resource Economics University of Rhode Island Kingston, RI 02881 USA, accessed $3^{\text {rd }}$ October 2010

Thamizhselvan and Murugan. 2012. Marketing of Grapes in Theni District. International Journal of Marketing and Technology. 9(2):96-111. http://www.ijmra.us

Taylor D.H. 2005. Value chain analysis: an approach to supply improvement in agri-based chain. International Journal of Physical Distribution \& Logistic Management 35: 744-761pp

WorldFish, C. 2011. Review of Aquaculture and Fish Consumption in Bangladesh. 